\title{
Vitamin D-dependency Rickets in Institutionalized, Mentally Retarded Children on Long Term Anticonvulsant Therapy. II. The Response to 25-Hydroxycholecalciferol and to Vitamin $\mathrm{D}_{2}$
}

\author{
Noel Maclaren \\ University of Maryland School of Medicine, Department of Pediatrics, Baltimore, and Rosewood State Hospital, Owings Mills, \\ Maryland, USA \\ Fima Lifshitz ${ }^{[45]}$ \\ Department of Pediatrics, North Shore University Hospital, Manhasset, and Department of Pediatrics, Cornell University Medical College, \\ New York, New York, USA
}

\section{Extract}

Eight mentally retarded children with vitamin D-dependency rickets associated with long term anticonvulsant medication are reported. All had been institutionalized for most of their lives, and had marked cerebral palsy. Their ages ranged from 3.5-9.5 years. All suffered from a chronic convulsive disorder and had been treated for 3 years or more with various combinations of Dilantin, Mysoline, and phenobarbital. They had no alterations in hepatic, renal, or intestinal functions.

Rickets ensued in these children despite an intake of conventional doses of oral vitamin $D_{2}$ taken prophylactically throughout life. Three patients failed to respond to treatment with doses of up to $6,000 \mathrm{IU} / 24 \mathrm{hr}$ given orally. In one instance, 2,000 IU vitamin $\mathrm{D}_{2}$ was given for 7 months, with no response. However, in three patients, healing was induced with higher doses of vitamin $\mathrm{D}_{2}$; one healed with $15,000 \mathrm{IU}$ vitamin $\mathrm{D}_{2}$ daily for 10 weeks, and two responded to a single oral dose of vitamin $\mathrm{D}_{2}$ of $600,000 \mathrm{IU}$. Another patient did not improve after one single oral dose of $0.5 \mathrm{mg}$ dihydrotachysterol. In contrast, 50 IU 25-hydroxycholecalciferol daily by mouth induced rapid healing in five patients. There was a rapid rise in serum $\mathrm{PO}_{4}$ levels within the lst week of this therapy, with radiographic healing apparent after 1 month. However, the serum calcium levels remained low throughout 4-5 months of therapy. When the dose of 25hydroxycholecalciferol $\left(25-\mathrm{OH}-\mathrm{D}_{3}\right)$ was increased to $100 \mathrm{IU} / 24 \mathrm{hr}$, the hypocalcemia was corrected. In some of these patients there was an amelioration of convulsions after rickets was treated. It is suggested that children who reside in institutional care centers, who are on long term anticonvulsant drugs, be given vitamin D supplements greater than the usual prophylactic dose, and also (perhaps more appropriately) that serial serum calcium, phosphate, and alkaline phosphatase estimations be performed regularly in such children as well as long bone radiographs when indicated.

\section{Speculation}

The rapid response to small dosages of $25-\mathrm{OH}-\mathrm{D}_{3}$ is evidence suggestive that the mechanism for rickets induction in patients on long term anticonvulsant therapy is one 
of interference of vitamin $\mathrm{D}$ metabolism at the stage of hepatic conversion from cholecalciferol to its 25-hydroxy metabolite. Other factors such as levels of sunlight exposure, relative inactivity, and chronic recurrent infections, may also play a role in the development of rickets in these patients.

\section{Introduction}

In 1965 Wright [38] was the first to recognize elevated serum alkaline phosphatase activity in up to $10 \%$ of adult epileptics receiving long term anticonvulsant therapy; in 1970 Richens and Rowe [33] described abnormalities in calcium metabolism in $29 \%$ of residential adult epileptics treated with high dosages of anticonvulsants. In 1968, Kruse [22] reported the presence of rickets occurring in institutionalized children who were mentally retarded and taking long term antiepileptic drugs, and in 1970 Dent $e t$ al. [10] described the occurrence of osteomalacia in adult epileptics. More recently, there have been several reports on this subject in the literature $[3,5,9,12-14,19,21,23,35,36]$.

Chronic phenobarbital ingestion has been shown to increase the rate of disappearance of ${ }^{3} \mathrm{H}$-vitamin $\mathrm{D}_{3}$ from plasma in humans (15-17). Liver microsomes from phenobarbital-treated animals are capable of increasing hydroxylation of steroid hormones $(7,20,24)$ and of converting ${ }^{3} \mathrm{H}$-labeled vitamin $\mathrm{D}_{3}$ and ${ }^{3} \mathrm{H}$-labeled 25-OH- $\mathrm{D}_{3}$ rapidly to more polar metabolites in vitro [15]. The serum concentrations of $25-\mathrm{OH}-\mathrm{D}_{3}$ may be reduced in adult epileptics with lower serum calcium levels and elevated alkaline phosphatase activity [16]. A rapid disappearance of $\left({ }^{3} \mathrm{H}\right)$ cholecalciferol was reported in an infant with rickets while on long term anticonvulsant treatment [13].

This report describes eight institutionalized, mentally retarded patients on long term anticonvulsant medication, who developed vitamin D-dependency rickets. The response to vitamin $\mathrm{D}_{2}$ and dihydrotachysterol given in oral doses appropriate for treatment of nutritional vitamin $\mathrm{D}$ deficiency as well as the response to low doses of $25-\mathrm{OH}-\mathrm{D}_{3}$ by mouth was evaluated. Prompt biochemical and radiographic improvements were induced with both large quantities of vitamin $\mathrm{D}_{2}$ and with $50 \mathrm{IU} / 24 \mathrm{hr} 25-\mathrm{OH}-\mathrm{D}_{3}$ [25].

\section{Materials and Methods}

The patients were children residents in Rosewood State Hospital, Owings Mills, Maryland. All were severely mentally retarded with marked cerebral palsy; they were bedridden, and lacked any exposure to sunlight. All received a diet adequate in calories, calcium, phosphate, and protein, although six had a weight at or below the third percentile. Three patients (patients $D D, S H$, and $B H$ ) suffered difficulty with feedings, and had been given three daily Sustagen tube feedings for 9-12 months prior to the study to fortify their diets. These tube feedings were tolerated well. The remainder of the patients were fed as well as the other children in the wards. The patients received supplemental vitamin $\mathrm{D}_{2}$ in the form of multivitamin drops throughout life in addition to the vitamin $D_{2}$ in foods and fortified milk. A daily vitamin $\mathbf{D}_{2}$ intake of approximately $800-1,200$ IU had been taken by all since admission. All medications, including daily vitamin supplements, given in the wards housing the patients in this study were closely supervised by a single "medication's team" of nursing personnel. The eight patients in this study were on long term anticonvulsant therapy and were found to have biochemical and roentgenologic rickets during a survey of serum $\mathrm{Ca}, \mathrm{P}$, and alkaline phosphatase concentrations among 288 Rosewood State Hospital residents of less than 15 years of age. The results of this survey will be published elsewhere [26]. Some of the pertinent clinical data for these patients are summarized in Table I. None had clinical or biochemical evidence of liver, kidney, or intestinal disease.

The response to vitamin $\mathrm{D}$ therapy was evaluated by the changes in serum concentrations of calcium [39], phosphorus [11], and alkaline phosphatase [40] obtained after an overnight fast and by the changes occurring in long bone radiographs. The purified 25$\mathrm{OH}-\mathrm{D}_{3}$ was dissolved in peanut oil at a concentration of $50 \mathrm{IU} / \mathrm{ml}$ [41].

\section{Results}

The response to vitamin $D_{2}$ in doses of less than 6,000 $\mathrm{IU} / 24 \mathrm{hr}$ given orally to three patients is summarized in Table II. Patient KG failed to improve while taking 2,000 IU / $24 \mathrm{hr}$ day for 7 months. During this time, her serum alkaline phosphate remained high and the roentgenologic changes of rickets markedly worsened as shown in Figure $1 A$. The two other patients $(M S t L$ and $S H$ ) failed to respond to 3,000 IU given daily for 3 and 4 weeks; $S H$ was followed with an increased dos- 
Table I. Pertinent clinical data ${ }^{1}$

\begin{tabular}{|c|c|c|c|c|c|c|c|}
\hline \multirow[b]{2}{*}{ Patient } & \multirow[b]{2}{*}{ Age, yr } & \multirow[b]{2}{*}{ Sex } & \multirow[b]{2}{*}{ Race } & \multirow[b]{2}{*}{ Diagnosis² } & \multicolumn{3}{|c|}{ Anticonvulsant medication } \\
\hline & & & & & Type & $\begin{array}{c}\text { Dose, } \\
\text { mg } / 24 \mathrm{hr}\end{array}$ & Duration, yr \\
\hline$D D$ & 4 & $\mathrm{~F}$ & $\mathrm{~N}$ & $\begin{array}{l}\text { Posthemophilus influenza; menin- } \\
\text { gitis } 10 / 12\end{array}$ & $\begin{array}{l}\mathrm{D} \\
\mathrm{P}\end{array}$ & $\begin{array}{l}25 \\
64\end{array}$ & $\begin{array}{l}3 \\
3\end{array}$ \\
\hline$K G$ & 7.5 & $\mathrm{~F}$ & $\mathrm{C}$ & Neonatal hypoglycemia & $\begin{array}{l}M \\
P\end{array}$ & $\begin{array}{r}375 \\
48\end{array}$ & $\begin{array}{l}7 \\
7\end{array}$ \\
\hline$M S t L$ & 8 & M & C & $\begin{array}{l}\text { Hydrancephaly and congenital hy- } \\
\text { drocephalus }\end{array}$ & $\begin{array}{l}\mathrm{D} \\
\mathrm{P}\end{array}$ & $\begin{array}{r}200 \\
48\end{array}$ & $\begin{array}{l}7 \\
7\end{array}$ \\
\hline$S H$ & 7 & $\mathrm{~F}$ & C & $\begin{array}{l}\text { Antepartum hemorrhage and birth } \\
\text { shock; myoclonic seizures }\end{array}$ & $\begin{array}{l}\mathrm{D} \\
\mathrm{P} \\
\mathrm{C}\end{array}$ & $\begin{array}{r}50 \\
32 \\
300\end{array}$ & $\begin{array}{l}7 \\
7 \\
3\end{array}$ \\
\hline$J C$ & 8.5 & M & $\mathrm{N}$ & Encephalopathy; unknown etiology & $\begin{array}{c}\text { D } \\
\text { P } \\
\text { Diamox }\end{array}$ & $\begin{array}{r}100 \\
48 \\
500\end{array}$ & $\begin{array}{l}5 \\
5 \\
1\end{array}$ \\
\hline$B H$ & 4.5 & $\mathbf{M}$ & $\mathrm{N}$ & Porencephalic cyst & $\begin{array}{c}\text { M } \\
\text { D } \\
\text { P } \\
\text { Diamox }\end{array}$ & $\begin{array}{c}250 \\
60 \\
64 \\
500^{3}\end{array}$ & $\begin{array}{c}1.5 \\
1 \\
4\end{array}$ \\
\hline$M M$ & 3.5 & $\mathrm{~F}$ & C & Antepartum hemorrhage & $\begin{array}{c}\mathrm{D} \\
\mathrm{M} \\
\mathrm{C}, \mathrm{P}^{4}\end{array}$ & $\begin{array}{r}75 \\
250\end{array}$ & $\begin{array}{r}3 \\
11\end{array}$ \\
\hline$C J$ & 3.5 & $\mathrm{~F}$ & C. & $\begin{array}{l}\text { Congenital hydrocephalus and me- } \\
\text { ningomyelocele }\end{array}$ & $\begin{array}{l}\mathrm{D} \\
\mathrm{P}\end{array}$ & $\begin{array}{l}32 \\
16\end{array}$ & $\begin{array}{l}3 \\
3\end{array}$ \\
\hline
\end{tabular}

${ }^{1} \mathrm{~F}$ : female; $\mathrm{M}$ : male; $\mathrm{N}$ : Negro; C: Caucasian; M : Mysoline; D : Dilantin; P: phenobarbital; C: Celontin.

2 All patients were severely mentally retarded and had marked cerebral palsy. They were nonambulatory, lacked any exposure to sunlight, and had chronic recurrent infections.

${ }^{3}$ Used prior to 3 years of age.

4 Used prior to 2 years of age.

age of 6,000 IU daily for a further 2 weeks with no biochemical and roentgenologic evidence of improvement (Fig. 2). Another patient, $J C$, failed to improve after one single oral dose of $0.5 \mathrm{mg}$ of dihydrotachysterol (Table II). He showed continued hypocalcemia, hypophosphatemia, elevated alkaline phosphatase activity, and radiographic rickets throughout the ensuing 40 days. However, patients with vitamin D-dependency rickets associated with long term anticonvulsants responded to larger doses of vitamin $\mathbf{D}_{2}$ given orally (Table III). One patient (MStL) showed healing within 2 months of $15,000 \mathrm{IU} / 24 \mathrm{hr}$ without changes in anticonvulsants. Thereafter rickets healed and serum calcium, phosphorus, alkaline phosphatase, and bone radiographs have remained normal with 1,200 IU / $24 \mathrm{hr}$ for 1 year. A single oral dose of 600,000 IU vitamin $\mathrm{D}_{2}$ produced a rapid response in blood chemistries (Table III) and in serial radiographs (Fig. $1 A$ and $1 B$ ). The two patients who received this treatment
( $D D$ and $K G$ ) had biochemical and radiographic evidence of rickets; $D D$ showed a severe hypophosphatemia of $0.76 \mathrm{mg} / 100 \mathrm{ml}$. This patient had had a spontaneous fracture of the lower femur 9 months previously, and subsequently suffered another spontaneous greenstick fracture of the other femur (Fig. 1B) 3 days after blood was drawn in the survey of all children [26]. After the large single oral dose of vitamin $\mathrm{D}_{2}$, both patients showed a prompt elevation of serum phosphate concentrations within 5 days, but both had high values for the serum alkaline phosphatase activity for as long as 5 months. The x-rays showed evidence of healing within 2 weeks of vitamin $\mathrm{D}_{2}$ administration (Fig. 1 $A$ ).

In contrast, the response of patients to $50 \mathrm{U}$ orally administered 25-OH-D ${ }_{3}$ daily was prompt (Figs. 2, 3, and 4). A rapid rise in fasting serum phosphate levels was noted within the 1st week of therapy in the five patients given this medication. All but one $(M M)$ at- 
Table 1I. Response to vitamin $\mathrm{D}_{2}$ in doses of less than 6,000 $\mathrm{IU} / 24 \mathrm{hr}$ given orally, and a single dose of $0.5 \mathrm{mg}$ dihyrotachysterol

\begin{tabular}{|c|c|c|c|c|c|}
\hline \multirow{2}{*}{ Palient } & \multirow{2}{*}{ Day } & \multicolumn{2}{|c|}{ Serum, $\mathrm{mg} / 100 \mathrm{ml}$} & \multirow{2}{*}{$\begin{array}{c}\text { Alkaline } \\
\text { phos- } \\
\text { phatase, } \\
\text { K-A U' }\end{array}$} & \multirow{2}{*}{$\begin{array}{c}\text { Roentgenologic } \\
\text { rickets }\end{array}$} \\
\hline & & $\mathrm{Ca}$ & $P$ & & \\
\hline \multirow[t]{4}{*}{$\kappa G$} & $\begin{array}{l}1 \\
3^{2}\end{array}$ & 8.9 & 3.4 & 100 & Moderate \\
\hline & 31 & 8.8 & 3.4 & 100 & \\
\hline & 186 & 9.1 & 4.3 & 179 & \\
\hline & 210 & 9.2 & 4.1 & 183 & Severe \\
\hline \multirow[t]{2}{*}{$M S t L$} & $\begin{array}{l}1 \\
7^{3}\end{array}$ & 8.0 & 2.2 & 100 & Moderate \\
\hline & 33 & & & & Moderate \\
\hline \multirow[t]{5}{*}{$S H$} & $\begin{array}{l}1 \\
2^{4}\end{array}$ & 8.1 & 2.9 & 78 & Severe \\
\hline & 7 & 8.0 & 3.7 & 71 & \\
\hline & 17 & 8.0 & 3.2 & 78 & Severe \\
\hline & $\begin{array}{l}22 \\
23^{5}\end{array}$ & 9.4 & 1.6 & 75 & \\
\hline & 36 & 8.9 & 2.7 & 65 & Severe \\
\hline \multirow[t]{4}{*}{$J C$} & $\begin{array}{l}1 \\
2^{6}\end{array}$ & 8.7 & 2.8 & 42 & Moderate \\
\hline & 4 & 8.9 & 2.9 & 48 & \\
\hline & 6 & 8.8 & 2.9 & 38 & \\
\hline & 40 & 8.0 & 2.8 & 39 & Moderate \\
\hline
\end{tabular}

${ }^{1} \mathrm{~K}-\mathrm{A}$ U: King-Armstrong units.

${ }_{2}$ On day 3, vitamin $\mathrm{D}_{2}, 2,000 \mathrm{IU} / 24 \mathrm{hr}$, was begun.

${ }^{3} \mathrm{On}$ day 7 , vitamin $\mathrm{D}_{2}, 3,000 \mathrm{IU} / 24 \mathrm{hr}$, was begun.

${ }^{4} \mathrm{On}$ day 2, vitamin $\mathrm{D}_{2}, 3,000 \mathrm{IU} / 24 \mathrm{hr}$, was begun.

${ }^{5}$ On day 23 , vitamin $\mathrm{D}_{2}$ was increased to $6,000 \mathrm{IU} / 24 \mathrm{hr}$.

6 On day 2, a single dose of dihydrotachysterol, $0.5 \mathrm{mg}$, was given orally.

tained serum phosphate levels above $3.5 \mathrm{mg} / 100 \mathrm{ml}$. In $M M$ however, the serum phosphate rose from 1.1 to $2.9 \mathrm{mg} / 100 \mathrm{ml}$ within 3 days of therapy, and after 1 month the level was above $3.5 \mathrm{mg} / 100 \mathrm{ml}$. The serum calcium levels decreased after treatment with $50 \mathrm{IU}$ 25-OH-D $\mathrm{D}_{3}$ daily (Fig. 4). In one instance $(\mathrm{SH})$, a fall in serum calcium levels to $7.7 \mathrm{mg} / 100 \mathrm{ml}$ within the first 4 days of therapy was noted. However, the serum calcium concentrations ranged between 7.2 and $9.3 \mathrm{mg} /$ $100 \mathrm{ml}$ in all patients, although the hypocalcemia was asymptomatic. Patients $J C$ and $B H$ had persisting low serum calcium levels between 8.0 and $9.0 \mathrm{mg} / 100 \mathrm{ml}$ even after 4 to 5 months of therapy. However, when the dose of $25-\mathrm{OH}-\mathrm{D}_{3}$ was increased to $100 \mathrm{IU} / 100 \mathrm{ml}$ by mouth, the serum calcium concentrations rose rapidly above $9.0 \mathrm{mg} / 100 \mathrm{ml}$ (Fig. 5) in the two patients treated with this increased dosage ( $S H$ and $M M$ ). The serum alkaline phosphatase activity remained high in the patients treated with $25-\mathrm{OH}-\mathrm{D}_{3}$ for as long as 6 months.
Radiographic improvement of rickets also occurred after treatment with small dosages of $25-\mathrm{OH}-\mathrm{D}_{3}$ as shown in Figures 2 and 3. Within 1 month of therapy there was evidence of healing in all patients. In $p a$ tient $C J$, who had mild rickets, this dose was sufficient to induce complete healing within 4 weeks. Patient $J C$ had slow healing after 3 months of $50 \mathrm{IU} 25-\mathrm{OH}-\mathrm{D}_{3}$ daily but healing was complete after a further 2 months of 100 IU daily (Fig. 3). However, persistent osteoporosis was still evident after 4-6 months of therapy in all patients.

One patient, patient $C J$, received $25-\mathrm{OH}-\mathrm{D}_{3}$ therapy for 1 month. During this time the serum Ca, P, and alkaline phosphatase activity were corrected and the



Fig. 1. The response to vitamin $\mathbf{D}_{2}$ therapy. A: patient $K G$. Radiographs of the wrist. 1 : mild rickets at the time of initial diagnosis; 2: worsening rickets after 210 days of treatment with $2,000 \mathrm{IU} / 24 \mathrm{hr}$ of added vitamin $\mathrm{D}_{2}$ by mouth; 3: healing rickets evident 15 days after a single oral dose of $600,000 \mathrm{IU}$ vitamin $\mathrm{D}_{2}$. Serum chemistries for this patient are shown in Tables II and III. B: patient DD. Radiographs of the knee. 1: greenstick fracture of the lower femur with severe rickets; 2: healing evident with calcified osteoid, 40 days after a single oral dose of $600,000 \mathrm{IU}$ vitamin $\mathbf{D}_{2}$. Radiographic healing of rickets was seen after 3 months but osteoporosis was still present. Serum chemistries for patient $D D$ shown in Table III. 


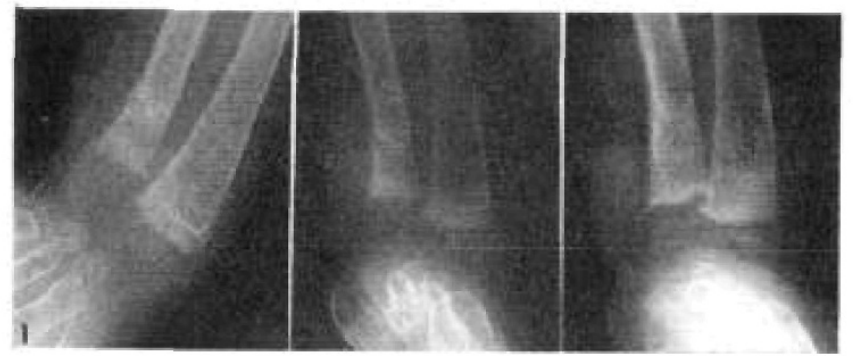

Fig. 2. The response to vitamin $\mathrm{D}_{2}$ and 25 -hydroxycholecalciferol therapy in patient $S H$. Radiographs of the wrist. 1: severe rickets and a partially healed fracture of lower ulna at initial diagnosis; 2: essentially no change after 5 weeks of oral vitamin $D_{2}$ therapy $\left(3,000 \mathrm{IU} / 24 \mathrm{hr}\right.$ added vitamin $\mathrm{D}_{2}$ for 4 weeks, and $6,000 \mathrm{IU} / 24 \mathrm{hr}$ the last 2 weeks); 3 : marked healing after 45 days of 50 IU 25 hydroxycholecalciferol given daily by mouth.

Table III. Response to oral vitamin $\mathrm{D}_{2}$ in doses of $15,000 \mathrm{IU} /$ $24 \mathrm{hr}$ given orally, and a single oral dose of $600,000 \mathrm{IU}$

\begin{tabular}{|c|c|c|c|c|c|}
\hline \multirow{2}{*}{ Patient } & \multirow{2}{*}{ Day } & \multicolumn{2}{|c|}{ Serum, $\mathrm{mg} / 100 \mathrm{ml}$} & \multirow{2}{*}{$\begin{array}{l}\text { Alkaline } \\
\text { phos- } \\
\text { phatase, } \\
\mathrm{K}-\mathrm{A} \mathrm{U}^{1}\end{array}$} & \multirow{2}{*}{$\begin{array}{c}\text { Roentgenologic } \\
\text { rickets }\end{array}$} \\
\hline & & $\mathrm{Ca}$ & $P$ & & \\
\hline \multirow[t]{7}{*}{$M S t L$} & 33 & & & & Moderate \\
\hline & $34^{2}$ & & & & \\
\hline & 42 & 6.2 & 4.0 & & \\
\hline & 90 & 9.0 & 5.0 & 42 & Healing \\
\hline & $91^{3}$ & & & & \\
\hline & 120 & 9.0 & 4.0 & & \\
\hline & 380 & 9.3 & 4.5 & 28 & Healed \\
\hline \multirow[t]{8}{*}{$D D$} & 1 & 8.3 & 0.76 & 50 & Severe \\
\hline & 24 & & & & \\
\hline & 6 & 8.3 & 3.3 & 51 & \\
\hline & 10 & 8.6 & 4.9 & 43 & \\
\hline & 17 & 8.5 & 4.9 & 38 & Healing \\
\hline & 20 & 8.8 & 4.8 & 44 & \\
\hline & 87 & 9.5 & 4.8 & 40 & \\
\hline & 145 & 9.8 & 4.2 & 35 & Healed \\
\hline \multirow[t]{6}{*}{$K G$} & 210 & 9.2 & 4.1 & 183 & Severe \\
\hline & $211^{5}$ & & & & \\
\hline & 217 & 8.7 & 6.9 & 139 & \\
\hline & 221 & 9.1 & 7.5 & 105 & Healing \\
\hline & 225 & 9.0 & 6.0 & 90 & \\
\hline & 324 & 9.0 & 5.7 & 63 & Healed \\
\hline
\end{tabular}

${ }^{1} \mathrm{~K}$-A U: King-Armstrong units.

${ }^{2}$ On day 34 , vitamin $\mathrm{D}_{2}, 15,000 \mathrm{IU} / 24 \mathrm{hr}$, was begun.

${ }^{3}$ On day 91, vitamin $\mathrm{D}_{2}$ was reduced to $1,200 \mathrm{IU} / 24 \mathrm{hr}$.

4 On day 2 a single dose of vitamin $\mathrm{D}_{2}, 600,000 \mathrm{IU}$, was given.

5 On day 211 a single dose of vitamin $\mathrm{D}_{2}, 600,000 \mathrm{IU}$, was given.

radiographic rickets was markedly improved. After this medication was stopped she continued to improve and there was no evidence of rickets 4 months afterward, although the alkaline phosphatase activity remained slightly higher than normal.

There has been amelioration in the frequency and severity of convulsions in some of these patients after rickets was treated. Patients $K G, S H, J C$, and $M M$ had a reduction in seizure activity while on the same dose of anticonvulsant therapy. Patient $S H$, who had 6-10 seizures $/ 24 \mathrm{hr}$, now has had no seizures at all.

\section{Discussion}

The eight patients described further illustrate the association of vitamin D-dependency rickets and osteomalacia in institutionalized epileptics taking long term anticonvulsant therapy, and add to the growing literature on this subject $[3,5,9,10,12-14,19,21-23,33,35$, $36,38]$.

It is clear that, at least in institutionalized patients,
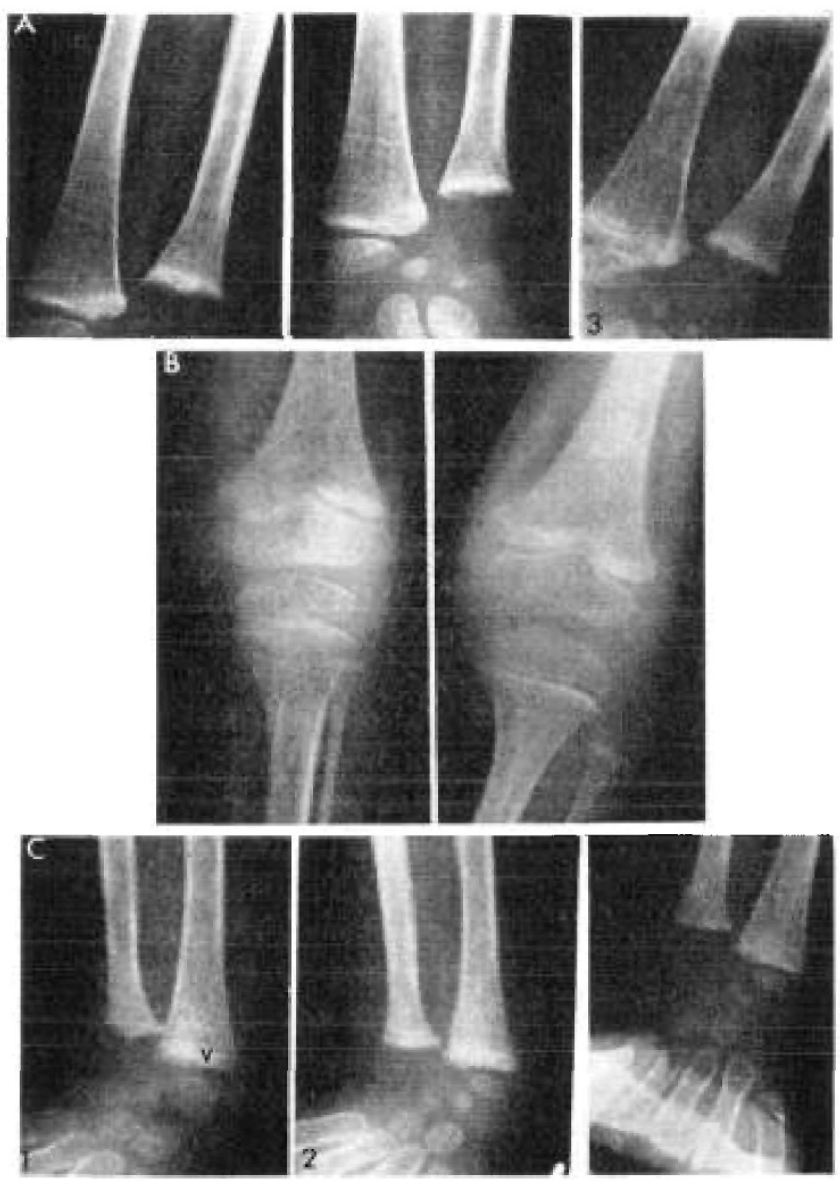

Fig. 3. The response to 25-hydroxycholecalciferol therapy in patient $J C(A)$, patient $B H(B)$, and patient $M M(C)$. Radiographs of wrists and knees. $A 1, B 1$, and $C 1$ : rickets at the time of initial diagnosis; $A 2, B 2$, and $C 2$ : evidence of healing 1 month after 50 $\mathrm{IU} / 24 \mathrm{hr}$ 25-hydroxycholecalciferol given orally; $A 3$ and $C 3: 4$ months after 25-hydroxycholecalciferol was begun. Serum chemistries for $J C$ are shown in Table II, and for $B H$ and $M M$ are shown in Fig. 4. 


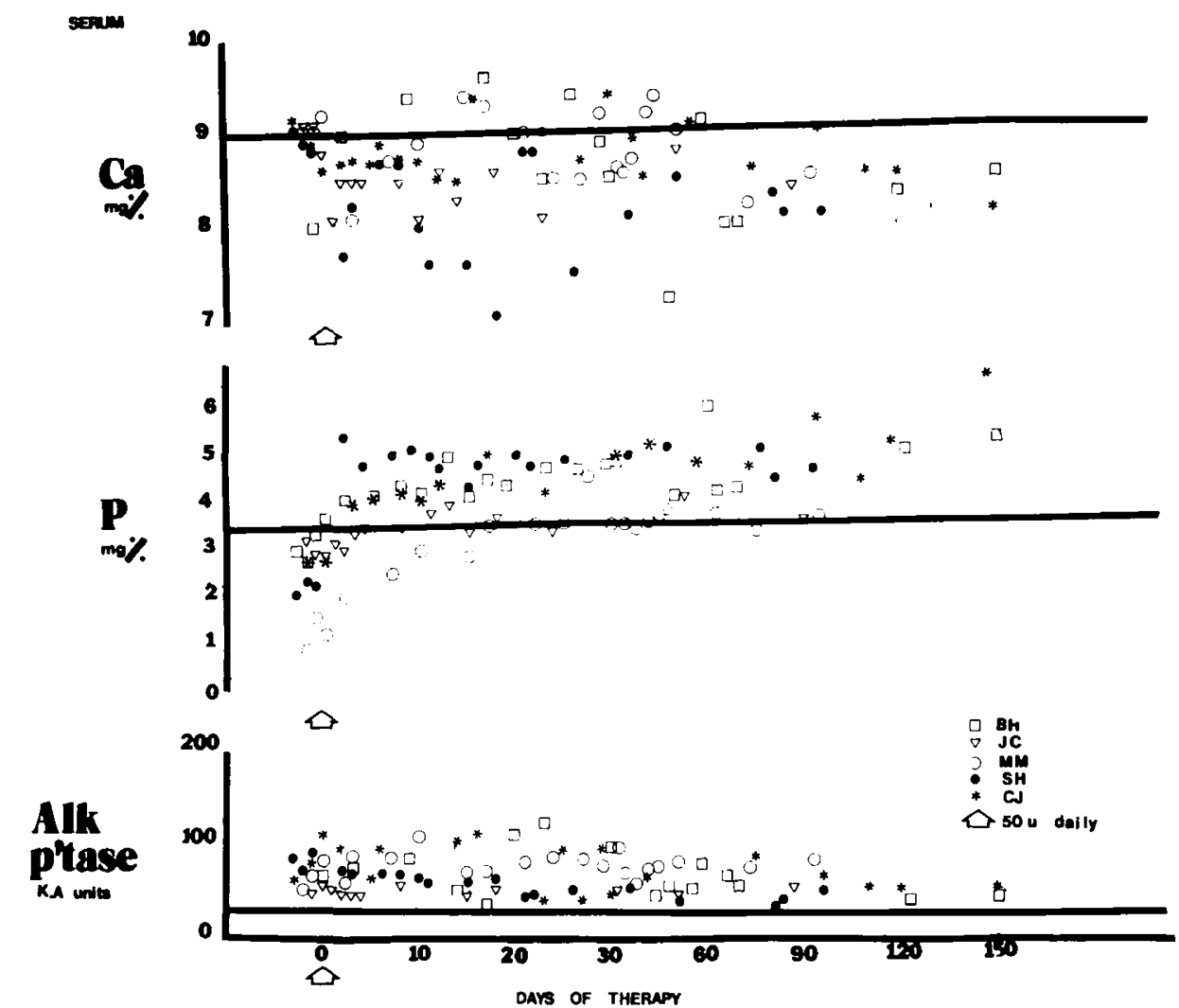

Fig. 4. The response to 25 -hydroxycholecalciferol given daily. Alk p'tase: alkaline phosphatase.

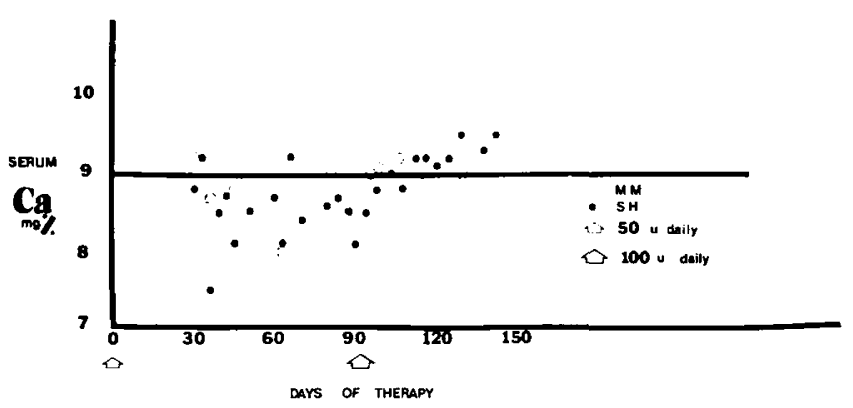

Fig. 5. The response to 25-hydroxycholecalciferol given orally.

vitamin $\mathrm{D}$-dependency rickets may occur in association with long term anticonvulsant medication, despite the prophylactic administration of conventional doses of vitamin $\mathrm{D}_{2}$. A $3.5 \%$ incidence of definite biochemical and radiographic rickets was demonstrated in our survey of 288 institutionalized residents of less than 15 years of age [26]. Rickets occurred in $7.0 \%$ of patients who were taking anticonvulsants, particularly those receiving a combination of anticonvulsants for more than 1 year. The patients with rickets lacked any exposure to sunlight and had chronic recurrent infections throughout life $[25,26]$.
Healing of rickets was rapidly induced with pharmacologic doses of vitamin $\mathrm{D}_{2}$ appropriate for a deficiency state of the vitamin. Single doses of 600,000 IU vitamin $\mathrm{D}_{2}$ induced prompt healing in two of our patients. In one report $50,000 \mathrm{IU}$ of vitamin $\mathrm{D}_{2}$ given daily also induced rapid recovery [5]. Less than 6,000 IU vitamin $\mathrm{D}_{2}$ therapy given daily even for prolonged periods may fail to induce healing changes, as seen in three of our patients and as reported by others $[5,16]$. Small doses of $25-\mathrm{OH}-\mathrm{D}_{3}$ given daily by mouth, however, induced rapid healing in our patients.

It has been shown by Avioli [1] and DeLuca [8] that calciferol must be transformed metabolically before becoming biologically active: i.e., a 25-hydroxylation reaction to form 25-OH-D $\mathrm{D}_{3}$ in the liver, and a 1-hydroxylation step to 1,25-dihydroxycholecalciferol in the kidney. The hypothesis that vitamin $\mathrm{D}_{3}$ must be enzymatically converted in the liver to $25-\mathrm{OH}-\mathrm{D}_{3}$ has been supported by several lines of evidence $[4,29,32]$. Reduced serum levels of $25-\mathrm{OH}-\mathrm{D}_{3}$ have been found in patients with disturbed calcium metabolism while on long term Dilantin and phenobarbital therapy [17]. The fact that our patients responded to small daily doses of $25-\mathrm{OH}$ - 
$\mathrm{D}_{3}$ given orally suggests an interference in the formation of $25-\mathrm{OH}-\mathrm{D}_{3}$ from calciferol in patients on long term anticonvulsant therapy.

It has been postulated that an accelerated catabolism of vitamin $\mathrm{D}_{2}$ and $25-\mathrm{OH}-\mathrm{D}_{3}$ is present in patients who receive anticonvulsant medication [15, 16, 33]. This hypothesis has been supported by several lines of investigation in vizo. Experimental data has shown an increased hepatic microsomal enzyme activity with increased hydroxylation of steroid hormones [7, 20,24], an increased disappearance rate of injected ${ }^{3} \mathrm{H}$-labeled vitamin $\mathrm{D}_{3}$ in humans and rats treated with phenobarbital, and an increased formation of more polar metabolites which lack biological activity $[7,15,16]$. An increased disappearance rate of injected ${ }^{3} \mathrm{H}$-vitamin $\mathrm{D}_{3}$ was also shown in a child with vitamin D-dependency rickets associated with anticonvulsant medication [13]. However, the prompt response elicited with small amounts of 25-OH-D ${ }_{3}$ in our patients could not be explained by a short half-life of vitamin $\mathrm{D}_{2}$ and 25$\mathrm{OH}-\mathrm{D}_{3}$. The decreased serum $25-\mathrm{OH}-\mathrm{D}_{3}$ level [17] may reflect a decreased formation of this metabolite rather than accelerated metabolism.

Despite a wide clinical usage of anticonvulsant drugs in various combinations for many years, reports of rickets and disorders of calcium metabolism have been relatively sparse except for those concerning institutionalized patients. Livingston [27] has tested routinely thousands of children coming to his outpatient department without discovering a single case of rickets. The serum levels of $25-\mathrm{OH}-\mathrm{D}_{3}$ have been correlated with the dosage of anticonvulsants [17]. The possibility that more brain-damaged, severely retarded institutionalized children had more refractory seizures could be considered. However, none of our patients with rickets received excessive dosages of anticonvulsant drugs per kilogram of body weight. Rickets was found only in nonambulatory, severely retarded patients with cerebral palsy who lacked exposure to sunlight and had chronic recurrent infections. Patients who had normal outdoor activities had no rickets despite long term anticonvulsant therapy $[25,26]$.

Rats fed Dilantin did not develop rickets [6]. Harrison and Harrison [18] found similar results with other anticonvulsants. It would seem from the above that there may be other contributing factors in institutionalized patients who develop vitamin D-dependency rickets while taking long term anticonvulsant drugs.

Lack of sunlight exposure may be an important factor in the development of rickets in institutionalized patients. It was of interest that Dent et al. [10] used ultraviolet light treatment on his patients with success as an adjunct to vitamin $\mathrm{D}$ therapy. Chronic infections have been associated with rickets for a long time. Park demonstrated the effect of bacterial infections on the development of rickets [30, 31]. All of our patients with vitamin D-dependency rickets frequently had pneumonia, other infections, and chronic dental abscesses.

Our patients showed a tendency toward falling calcium levels after starting 25-OH- $\mathrm{D}_{3}$ therapy. This was probably the effect of the low doses used, since the bone uptake of calcium exceeded the supply. A direct effect of $25-\mathrm{OH}-\mathrm{D}_{3}$ on bone calcium transport has been postulated since stimulation of bone resorption in tissue culture by this metabolite has been shown [37]. After therapy, the alkaline phosphatase levels were slow to fall in our patients. Again, the low doses of vitamin $\mathrm{D}_{2}$ used, and persistent bone disease, may be the explanation. However, it has been shown that the liver alkaline phosphatase isoenzyme might be considerably elevated in some of these patients [16]. In all of our patients the liver isoenzyme proved to be a major component of the total serum alkaline phosphatase levels, even though considerable bone disease was present [28].

The vitamin $\mathrm{D}_{2}$ metabolite, 25-OH- $\mathrm{D}_{3}$, employed for treatment of these patients has been shown to be more potent and to have a more rapid onset of action than vitamin $\mathrm{D}_{3}$ itself [4]. Comparative studies in rats showed that $25-\mathrm{OH}-\mathrm{D}_{3}$ possessed $1-4$ times the biological activity of vitamin $\mathrm{D}_{3}[4]$ and in children with various forms of rickets the maximum antirachitic potency of $25-\mathrm{OH}-\mathrm{D}_{3}$ was $5-8$ times that of the parent vitamin [2]. Since only $50 \mathrm{IU} 25-\mathrm{OH}-\mathrm{D}_{3}$ were used in this study, the healing effect of the daily dose was impressive. Of interest was the apparent prolonged action of $25-\mathrm{OH}-\mathrm{D}_{3}$. One of our patients healed after 1 month of therapy with $50 \mathrm{IU} / 24 \mathrm{hr}$ of these compounds and had no evidence of relapse 4 months after therapy was discontinued. This speaks against an effect of anticonvulsants in accelerating the degradation of $25-\mathrm{OH}$ $\mathrm{D}_{3}[15,16,33]$. The half-life of $25-\mathrm{OH}-\mathrm{D}_{3}$ has been shown to be $19.6 \pm 0.6$ days in man [34]. At present there is no evidence that this metabolite can be stored in the body. However, others have also reported a persistent effect of $25-\mathrm{OH}-\mathrm{D}_{3}$ in healing various types of rickets [2].

In treating these patients with vitamin D-dependency rickets associated with long term anticonvulsant 
medication, moderately large doses of vitamin $\mathbf{D}$ had to be administered either as a large single dose, or as smaller daily doses [5]. One patient healed satisfactorily on 15,000 IU vitamin $\mathrm{D}_{2}$ given daily. If $25-\mathrm{OH}-\mathrm{D}_{3}$ were to be used, ideally the dose should be several fold those used in this study in order to hasten recovery and to avoid hypocalcemia.

Prophylactic vitamin $\mathrm{D}_{2}$ therapy at dosages several fold that usually employed should be given to institutionalized epileptic children on long term anticonvulsant therapy. In addition, regular checks of serum alkaline phosphatase, calcium, and phosphates are necessary, as well as long bone radiographs when indicated by abnormal results of the serum analysis. It was of considerable interest that the frequency and severity of convulsion ameliorated with vitamin D therapy and healing of rickets. The mechanisms of this effect can only be speculative; however, further studies are indicated.

\section{Summary}

Fifty units per $24 \mathrm{hr}$ of $25-\mathrm{OH}-\mathrm{D}_{3}$ promptly induced healing in children with vitamin D-dependency rickets associated with long term anticonvulsant therapy who had shown resistance to doses of vitamin $\mathrm{D}_{2}$ of less than 6,000 $\mathrm{IU} / 24 \mathrm{hr}$. Inasmuch as the potency of 25$\mathrm{OH}-\mathrm{D}_{3}$ has been calculated to be 5-8 times that of vitamin $D_{2}$, these observations suggest that the pathogenesis of rickets in mentally retarded individuals on long term anticonvulsant therapy may be the result of an interference of the conversion of cholecalciferol to

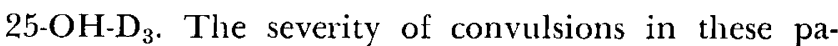
tients showed an improvement coincident with healing of rickets.

\section{References and Noles}

1. Avioli, L. V.: Current concepts of vitamin $\mathrm{D}_{3}$ metabolism. In: H. F. DeLuca and J. W. Suttie: The Fat Soluble Vitamins, p. 11 (University of Wisconsin Press, Madison, Wisc., 1970).

2. Balsam, S., and GaRabedian, M.: 25-Hydroxycholecalciferol: A comparative study in deficiency rickets and different types of resistant rickets. J. Clin. Invest., 51: 749 (1972).

3. BIASINI, G. C.: Crisi tetanica in soggetto trattato con anticonvulsivi. Minerva Pediat., 23: 1798 (1971).

4. Blunt, J. W., Tanaka, Y., and Deluca, H. F.: The biological activity of 25-hydroxycholecalciferol, a metabolite of vitamin $D_{3}$. Proc. Nat. Acad. Sci. U.S.A., 61: 1503 (1968).

5. Borgstedt, A., Bryson, M., Young, L., AND Forbes, G.: Longterm administration of antiepileptic drugs and the development of rickets. J. Pediat., 81 : 9 (1972).

6. Clark, R. L., Kuhn, J. P., and DeJorne, C. A.: Absence of rickets after chronic Dilantin administration: Experimental radiological observations in rats. Invest. Radiol., 56: 152 (1971).

7. ConNey, A. H.: Pharmacological implications of microsomal enzyme induction. Pharmacol. Rev., 19: 317 (1967).

8. DeLucA, H. F.: Vitamin D: A new look at an old vitamin. Nutr. Rev., 29: 179 (1971).

9. Deluca, K., et al.: Altered calcium metabolism due to anticonvulsant drugs. Develop. Med. Child Neurol., 1t: 318 (1972).

10. Dent, C. E., Richens, A., Rowe, D. J. F., and Stamp, T. C. B.: Osteomalacia with long-term anticonvulsant therapy in epilepsy. Brit. Med. J., 4: 69 (1970).

11. Fiske, C. H., and SubbaRow, J.: The colorimetric determination of phosphorus, J. Biol. Chem., 66: 375 (1925).

12. Frame, B.: Hypocalcemia and osteomalacia associated with anticonvulsant therapy. Ann. Intern. Med., 74: 294 (1971).

13. Genel, M., Berman, P. H., Marrow, A., and Bongiovanni, A. M.: Vitamin D dependency with dibasic aminoaciduria associated with anticonvulsant therapy. Pediat. Res., 6: 4 (1972).

14. Genuth, S. M., Klein, L., Rabinovich, S., King, K. C., AND Bontin, B.: Osteomalacia accompanying chronic anticonvulsant therapy. J. Clin. Endocrinol. Metab., 35: 378 (1972).

15. Hahn, T. J., Birge, S. J., Scharp, C. R., and Avioli, L. V.: Phenobarbital induced alterations in vitamin $\mathrm{D}$ metabolism. J. Clin. Invest., 51: 741 (1972).

16. Hahn, T. J., Hendin, B. A., Scharp, C. R., ANd Haddad, J. G.: Effect of chronic anticonvulsant therapy on serum 25 hydroxycholecalciferol in adults. New Engl. J. Med. 287: 900 (1972).

17. Hahn, T. J., Scharp, C. R., Haddad, J. C., and Herdin, B. A.: Effect of anticonvulsant therapy of serum $25 \mathrm{OH}$ vitamin D levels. Clin. Res., 2: 238 (1972).

18. Harrison, H. E., and Harrison, H. C.: Personal communication.

19. Hunter, J., Maxwell, J. C., Stewart, D. A., Parsons, V., AND Williams, R.: Altered calcium metabolism in epileptic children on anticonvulsants. Brit. Med. J., 4: 202 (1971).

20. Jubiz, W., Welch, R. M. ANd ConNey, A. H.: Effect of diphenylhydantoin on the metabolism of dexamethasone: Mechanism of the abnormal dexamethasone suppression in humans. New Engl. J. Med., 283: 11 (1970).

21. Kazamatsuri, H.: Elevated serum alkaline phosphatase levels in epileptic patients treated with diphenylhydantoin. Folia Psychiat. Neurol. Jap., 2f: 181 (1970).

22. KruSE, R.: Osteopathies bei antiepileptischer. Langeihterapie (Vorlanfige Metteilung) Monatsch. Kingerheilkd., 116: 378 (1968).

23. Lefebore, E. B., Hoining, R. G., and Labbe, R. F.: Coarse facies, calvarian thickening and hyperphosphatism associated with long-term anticonvulsant therapy. N. Engl. J. Med., 286: 1301 (1972).

24. Levin, W., Welch, R. M., AND ConNey, A. H.: Effect of chronic phenobarbital treatment on the liver microsomal metabolism and uterotrophic action of $17, \beta$-estradiol. Endocrinology, 80: 135 (1967).

25. Lifshitz, $F$., and Maclaren, N.: Vitamin $D_{2}$, dihydrotachysterol, and 25-hydroxycholecalciferol treatment of vitamin D dependency rickets associated with anticonvulsants. Fed. Proc., 32: 918 (1973). 
26. Lifshitz, F., AND Macharen, N.: Vitamin D dependency rickets in institutionalized mentally retarded children on long-term anticonvulsant therapy. I. A survey of 288 patients. J. Pediat., in press.

27. Livingsron, S.: Comprehensive Management of Epilepsy in Infants, Childhood, and Adolescence (Charles C Thomas, Publisher, Springfield, Ill., 1972).

28. Maclaren, N., AND Lifshitz, F.: Unpublished data.

29. Olson, E. B., And DeLuca, H. F.: 25-Hydroxycholecalciferol direct effect on calcium transport. Science, 165: 405 (1969).

30. PARK, E. A.: The imprinting of nutritional disturbances on the growing bone. Pediatrics, 33: 815 (1954).

31. PARK, E. A.: The influence of severe illness in rickets, Arch Dis. Childhood, 29: 369 (1954).

32. Ponchon, G., Kennan, A. L., and Deluca, H. F.: Activation of vitamin D by liver. J. Clin. Invest., 48: 2032 (1969).

33. Richens, A., AND Rowe, D. J. F.: Disturbance of calcium metabolism by anticonvulsant drugs. Brit. Med. J., 4: 73 (1970).

34. Smith, J. E., AND Goodman, D. S.: The turnover and transport of vitamin $\mathrm{D}$ and of a polar metabolite with properties of 25-hydroxycholecalciferol in human plasma. J. Clin. Invest., 50: 2159 (1971).

35. StogmanN, W.: Ossifikations storuingen bei anticonvulsiver Langzeitbehandlung. Pediat. Padol., 6: 280 (1971).

36. Sotaniemi, E. A., et al.: Radiologic bone changes and hy- pocalcemia with anticonvulsant therapy in epilepsy. Ann. Intern. Med., 77: 389 (1972)).

37. Trummel, C. L., Raisz, L. G., Blunt, J. W., and Deluca, H. F.: 25-hydroxycholecalciferol: Stimulation of bone resorption in tissue culture. Science, 163: 1450 (1969).

38. Wright, J. A.: Trinuride in the treatment of major epilepsy. Epilepsia, 6: 67 (1965)

39. Model 305 atomic absorption spectrophotometer, Perkin Elmer, Norwalk, Conn.

40. Colorimetric Data of Alkaline Phosphatase, Sigma Bulletin No. 104, Sigma Chemical Co., St. Louis, Mo.

41. This drug was kindly supplied and the dose assayed by Dr. H. DeLuca, Madison, Wisc. (lot 82071, notebook 1)

42. The technical help of Eilver Edwards, Janet Hall, Irene McQuay, and Sue Castelman was greatly appreciated.

43. Dr. N. Maclaren is a Fellow in Pediatric Endocrinology and Metabolism.

44. The present address of Dr. F. Lifshitz is: Department of Pediatrics, North Shore University Hospital, Manhasset, N. Y. 11030, and Cornell University Medical College, New York, N. Y. 10021 (USA).

45. Requests for reprints should be addressed to: F. LIFshrTz, M.D., Department of Pediatrics, North Shore University Hospital, Manhasset, N. Y. 11030, and Cornell University Medical College, New York, N. Y. 10021 (USA).

46. Accepted for publication June 22, 1973. 